\title{
Re-Branding and Its Effects on Consumer Perceptions: A Case Study of a Zimbabwean Bank
}

\author{
Africa Makasi \\ PhD student, University of KwaZulu-Natal, South Africa and Harare Institute of Technology, Zimbabwe \\ africa.makasi@yahoo.com
}

Krishna Govender

University of KwaZulu-Natal, South Africa and Regenesys Business School, South Africa

Nyasha Madzorera

Women's University in Africa (BSC student). Africa Makasi. Harare Institute of Technology. Department of Technopreneurship, Zimbabwe P.O. Box B.E 277.Belvedere, Harare, Zimbabwe. Email: africa.makasi@yahoo.com

\section{Doi:10.5901/mjss.2014.v5n20p2582}

\section{Abstract}

The purpose of this study is to investigate re-branding and its effects on consumer perceptions. Relevant theoretical data were critically reviewed, compared and contrasted as they relate to the topic of rebranding and consumer perceptions. A mixed research methodology was adopted hence the combination of questionnaires and interviews in the data collection process. The study used a sample size of thirty customer representatives and five staff members of a local bank which has recently rebranded. Data was gathered, recorded, analyzed and interpreted on the basis of the research objectives and research questions using the Statistical Package for social sciences (SPSS) software. The mean and standard deviations of the responses were 1.08 and 0.277 respectively which reflected respondents' strong positive impression of the bank after it rebranded. Based on these and other results, the study therefore established that rebranding has positive effects on consumers' perceptions and can be used as a marketing tool in order gain competitive advantage and has an impact on the financial performance of an organization.

Keywords: rebranding, consumer perceptions, marketing strategy, competitive advantage

\section{Introduction}

A gradual modification of the positioning and representation of the corporate brand is a natural aspect of managing the brand in response to the ever changing market environment (Gotsi \& Andripoulos, 2007). However when the company takes the process a bit further and attempts to change the already existing perception of the brand in the mind of stakeholders the process can be characterized as a rebranding (Muzellec \& Lambkin, 2006). According to Muzellec \& Stuart, (2006) there are two degrees of rebranding. Revolutionary rebranding completely destroys the old perception of the brand and builds a new, by changing name, logo and slogan. Evolutionary rebranding is not as drastic and changes one or two of the three attributes, while maintaining the main issues of the positioning. It has been chosen in this paper to draw on these definitions in order to investigate how rebranding influences consumer perceptions.

\section{Literature Review}

Kotler, (1992) defines a brand as a name, term, sign, symbol, or design, or a combination of them, intended to identify the goods or services of one seller or group of sellers and to differentiate them from those of competitors. At the same time Stern (2006) defines rebranding as changing the name of the company or its targeting and positioning, in an attempt to attach new meanings to the corporate brand and communicate them to the stakeholders. According to Aaker (1991), rebranding constitutes the basic for the corporate communications programme and for the consumer's awareness and images. In support, Keller (1998) adds that consumer's perspective of brand's name is directly associated to 
psychological attributes which enable us to create meaning. Boyle (2002) comments that a company might choose to rebrand as a corporate structural change in line with its current strategic marketing direction. The other reasons why a company will rebrand is the fact that they want to unite the organization behind one brand, align the culture, reestablish and reenergize the market position while at the same time embed a new vision, mission and values (Causon, 2004); whilst some companies would rebrand as a way of upgrading their company and market position (Rosenthal, 2003). Stuart and Muzellec (2004) notes that rebranding can be as a result of mergers and acquisitions, whereby the company then focuses on a new image and vision. Muzellec and Lambkin (2006) attributes rebranding to change to processes causing a change in company's structure, strategy or performance of sufficient magnitude to suggest the need for a fundamental redefinition of its identity. Johnson (2002) also suggests that rebranding's motive might be the need to break with their past. In this case, the organization has to plan a major strategic shift, which means that it has to rename its brand to make the transition between the past and the future and to be more transparent with their customers, clients and in general with all the market. When company's name has become associated with a negative event or a tragedy and so rebranding will enhance the company to have a new image and customer will have new perceptions of the company (Johnson, 2002). There are also external factors that might influence a company to rebrand (Boyle, 2002). Companies may rebrand as a tool to counter competition and maintain competitive advantage. The management of the organization can have concern over external perception of the organization and its activities thereby leading to a rebranding exercise (Lomax et al 2002).

\subsection{Rebranding Process}

Lomax and Mador (2006) argue that after the company has a clear idea why rebranding is necessary and what the company expects the results would be the planning and finally the execution of the rebranding strategy can be started. The key success factor in rebranding is to incorporate the internal stakeholders to the process. Daly \& Moloney (2004) noted that already in the planning stage the employees can be taken to the process of creating a new name. This motivates and gains support and commitment of employees, as well as train employees in the new company policies and procedures. Kaikati (2003) points out that a company must develop both communications and training programs, to spread the new brand message internally throughout all levels of the company. To the external stakeholders, in turn, the company might include customer and journalist promotion packages, advertising, sponsoring to its promotion strategy, (Griffin, 2002). Each rebranding process should be evaluated with the regards to its initial goals (Stuart and Muzellec, 2004) and possible changes made if they become evident, (Daly \& Moloney, 2004). Consequently, research before and after the change is vital, and continuity and consistency should always be in mind when exercising rebranding. Kaikati (2003) suggest that re-branding process consists of rebranding, re-structuring and re-positioning On the other hand, Muzellec and Lambkin (2006), suggest that rebranding process should consist of rebranding factors, rebranding goals, and rebranding process. According to Hatch \& Schultz (2003), corporate rebranding necessitates synergy between marketing, human resource management and strategy. Often the process is more complex and time consuming than the companies anticipate. Lomax and Mador, (2006) adds that the phases are more or less intertwined and overlapped. Even though corporate re-branding is an issue which is conducted in several levels in organization and it is assumed that the corporate re-branding process is purposeful and adaptive in interaction with several actors, here the phenomenon is described from the perspective of the internal development of a single organizational entity, a company.

\subsection{Establishing relationship between brand and customer}

Keller (2003) states that brands performs a strong tie which connects the product and the customers. He also reiterated that from customer's view, brands play some roles such as identification of source of product; show responsibility of product maker; promise, bond, or pact with maker of product; signal of quality and many other factors which part in the creation of a relationship between a customer and a brand. Kotler (2001) points out that the brand offers two key opportunities to grow the value of the customer asset. First, brands provide an opportunity for the firm to get a greater share of wallet from an existing customer through additional purchases of current brands and products or through purchases of new brands or brand extension products. Second, brands provide the opportunity to attract new customers through the strength of the overall perception of the brand in the marketplace or through the development of new brands or brand extensions that attract new customers, thereby growing the value of the customer asset. Recent researches show that brand equity is a bridge to connect brand and customer. As mentioned before Aaker (1991) defined brand equity as a set of brand assets and liabilities linked to a brand which can add to or subtract from the value provided by a product or service to a firm and/or to that firm's customers. Keller (1993) mentioned that customer-based brand equity 
occurs when the consumer has a high level of awareness and familiarity with the brand. This will make the customer to be able to have loyalty to the product or service so that he will buy the service and product only as compared to the competitors' thereby increasing revenue and market share. From this perspective of view, one can see that the Brand value depends on the customer (Keller, 1993). It is an important component of brand equity (Aaker, 1991 and Keller, 1993). People will often buy a familiar brand because they are comfortable with the brand (Aaker, 1991).Brand awareness can affect decisions about brands in the consideration set even if there are essentially no other brand associations (Keller, 1993).

\subsection{Brand ldentity and image}

Brand identity is made up of the core values, visions and key beliefs of the brand (Kapferer, 2008). As such, brand identity represents what the brand stands for and it communicates the purpose, principle, background and ambitions of the brand and what the company wants to become in the future as highlighted by another scholars (Van Gelder, 2005 and .Aaker 2010). When creating a brand identity companies should aim to give depth to a brand by regarding the brand as a product, an organization, a person and a symbol (Aaker, 2010). Kapferer (2008) reviews the importance of conceptualizing brand identity in a broader concept as further supported by view which states that in order to become passion brands, or likeable brands, they must not be hollow, but have a deep inner inspiration. They must also have character, their own beliefs, and as a result help consumers in their daily life, and also in discovering their own identity. As pointed out by Aaker (2010), brand identity is how the company wants the brand to be perceived, while brand image is concerned with how the brand is now perceived. The brand identity prism incorporates this view in the model, i.e. physique and personality define the sender (the company), while reflection and self-image define the recipient (the customer). Relationship and culture function as a means to fill in the gap between the sender and recipient, (Kapferer, 2008). Through marketing programs and advertising messages, companies are able to convey their brand ideas to customers, (Clow \& Baack, 2007). Customers decode these messages and make their own evaluations and interpretations resulting in a brand image, (Nandan, 2005). For this reason, it is vital for companies to communicate their messages as clearly as possible. Knapp (2000) further adds that the consumer's mind is influenced by thousands of impressions and messages daily, and it is therefore important that companies occupy a distinctive position in the mind of the consumer. The level of distinctiveness, impressions and perceived value all affect how genuine the brand appears to the consumer. From the customer point of view, the role of brand image serves several purposes. Clow and Baack (2007), list assurance as a key function of brand image for example in purchase decisions or in situations where the customer is unfamiliar with the product or service. From the company point of view, brand image can provide strong competitive advantage, increase brand loyalty and, e.g. reduce risk in buying decisions. According to Keller (1993), brand image and brand awareness together form what is known as brand knowledge. Keller (1993) refers to how knowledge of a brand forms a 'node' which is linked by the associations which provide that knowledge, these associations are brand image and brand awareness.

\subsection{Customer perceptions and rebranding}

Solomon et al (2006) defines perception as the process in which a person select, arrange and interpret stimuli, these stimuli are filtered and adjusted to become one's own view of the world. The same authors goes on to add that it is only when the customers' perceptions of the business, the products and the services are known that you truly know whether or not the business is going in the right direction. All interactions that occur between the customers and the business will ultimately affect the customers' view and image of the business. Light \& Kiddon (2009) discovered that the modern bank customer is more demanding than they used to be long ago. In line with this statement, Light \& Kiddon, (2009) adds that it is the bank's obligation to ensure product brand trust because information flow in the society today is faster than ever and that affects the customer and the bank. High brand equity contributes to a better competitive edge, (Kotler et al, 2010). Angur et al (1999) asserts that technological changes are causing banks to alter their strategies for services offered to both commercial and individual customers. It is within this rapidly changing environment that customer satisfaction and service quality are compelling the attention of all banking institutions because customer demands have become increasingly sophisticated (Light \& Kiddon, 2009). According to Skogland and Siguaw (2004), satisfaction may be defined as an overall evaluation of performance based on all prior experiences with a firm. Marketing activities are undertaken with the goal of changing or reinforcing the consumer mindset in some way. This includes thoughts, feelings, experiences, images, perceptions, beliefs and attitudes towards a brand, (Aaker ,1991). The value of the brand, and the effectiveness of marketing activities undertaken to affect the consumer mindset about a brand, is therefore often 
measured by evaluating changes in perceptual responses on advertised attributes (Romaniuk and Nicholls ,2005). Silver \& Berggren (2010) asserts that corporate branding is not easy to achieve in banking, mainly because the banks products are intangible; and such products are easily imitated, and usually launched at the same time as other banks. Employee satisfaction does have a positive influence on employee involvement (van Wegge et al., 2007), performance of employees (Wright T., 2007), the employees' customer satisfaction (Stock 2009) and many other factors. Therefore, a bank's corporate image has to be very powerful, in order to make a significant impact.

\section{Methodology}

In this study, a mixed methodology was adopted. A local Zimbabwean Bank which commands over $45 \%$ share of the market was used as a case of study. The researcher chose this bank because in Zimbabwe, it is one of the commercial banks which embarks on rebranding now and again while at the same time maintaining a competitive advantage. The researcher collected information from of 5 staff members and 35 customers. The researcher administered the questionnaires by divided them into two groups, one for corporate clients and the other for individual walk in clients. The corporate clients' questionnaires were administered through an arrangement with their account relationship managers, who later send the questionnaires to them. The total numbers of questionnaires sent to corporate clients were 10 whereas a total of 25 questionnaires were sent to individual clients. This was done so as to collect valid information representative of all the bank clients without prejudicing the other group of customers. The questionnaires for individual customers were administered during month end of January 2014 when most people would visits the bank in order to withdraw cash either from their salaries and businesses. The questionnaires were designed to measure consumers' perceptions on rebranding and how it had influenced their loyalty to the bank. The questionnaire for this research underwent a pilot testing with a small number of colleagues. These colleagues were able to check the language and grammatical spelling mistakes of the questionnaires. The pilot test provided an indication of the length of time needed to answer the questionnaire and provided early indicators on difficulties the researcher would face when collecting data. Therefore, the exercise assisted the researcher to refine questionnaires and interview questions to ensure that the questions asked are relevant and easily understandable in order to extract reliable responses from the targeted research sample. A reliability test for variables was conducted in order to find out how much we can rely on the questionnaire as a research instrument and an alpha value of 0.870 was obtained.

\section{Findings}

As shown on table 1 below, the mean and standard deviation of the responses are 1.08 and.277 respectively which shows that most of the responses sited that they had a positive impression of the bank after it rebranded. Most of the respondents agree that they had a positive impression of the bank after its rebranding exercise.

Table 1: One sample T Test

One-Sample Statistics

\begin{tabular}{|c|c|c|c|c|}
\hline & $\mathrm{N}$ & Mean & Std. Deviation & Std. Error Mean \\
\hline Impression after rebranding & 25 & 1.08 & .277 & .055 \\
\hline
\end{tabular}

One-Sample Test

\begin{tabular}{|c|c|c|c|c|c|c|}
\hline \multirow{2}{*}{} & \multicolumn{3}{|c|}{ Test Value = 1 } \\
\cline { 6 - 7 } & $\mathrm{T}$ & $\mathrm{df}$ & Sig. (2-tailed) & \multirow{2}{*}{ Mean Difference } & \multicolumn{2}{|c|}{ 95\% Confidence Interval of the Difference } \\
\cline { 6 - 7 } & & & & Lower & Upper \\
\hline Impression after rebranding & 1.445 & 24 & .000 & .080 & -.03 & .19 \\
\hline
\end{tabular}

\subsection{Pearson's Correlation analysis}

This statistical technique is used to determine if two variables are linearly related to each other. Most of the respondents agree that service brand quality is related to bank image of a bank. This is so because the image is built from how the consumers view the bank. Table 2 below shows that a strong positive correlation exist between the ability to improve its 
profits (performance). This is reflected by a positive factor of 0.536 . If the service delivery system and quality is poor then the image is tarnished thereby having a negative impact on the bank as a whole. In this case, the bank's rebranding exercise had a positive effect on the service quality thus consequently impacting on the customers' perceptions on the bank as a whole.

Table 2: Pearson correlation

\begin{tabular}{|ll|c|c|c|}
\hline \multicolumn{1}{|c|}{ Correlations } \\
\hline service quality & service quality & Bank image & Improved bank profits and returns \\
& Pearson Correlation & 1 & .264 & $.483^{*}$ \\
& Sig. (2-tailed) & & .202 & .014 \\
& $\mathrm{~N}$ & 25 & 25 & 25 \\
\hline Bank image & Pearson Correlation & .264 & 1 & $.536^{* *}$ \\
& Sig. (2-tailed) & .202 & & .006 \\
& $\mathrm{~N}$ & 25 & 25 & 25 \\
\hline Improved bank profits and returns & Pearson Correlation & $.483^{*}$ & $.536^{* *}$ & 1 \\
& Sig. (2-tailed) & .014 & .006 & 25 \\
& $\mathrm{~N}$ & 25 & 25 & 25 \\
\hline
\end{tabular}

*. Correlation is significant at the 0.05 level (2-tailed).

**. Correlation is significant at the 0.01 level (2-tailed).

\section{Discussions}

Since a strong relationship exists between the bank's image and the perceived quality of service (with a Pearson correlation factor of 0.536 ), it therefore confirms that a successful rebranding process is likely to change consumers' perceptions. Hatch \& Schultz (2003) posits that corporate rebranding necessitates synergy between marketing, human resource management and strategy. We therefore accept the proposition that rebranding can affect consumer perceptions and can influence loyalty to the bank based on the above results. All interactions that occur between the customers and the business will ultimately affect the customers' views and image of the business. Whichever form of rebranding is effected on the firm; whether revolutionary or evolutionary rebranding, the outcome is the same: that consumer perceptions will be affected (Muzellec and Stuart, 2004). The results show that brand identity should help establish a relationship between the brand and the customer. Therefore for the survival of banks and in order for them to keep abreast of competition it is imperative for them to adopt rebranding as a marketing tool.

Finally, results revealed that the performance of any organization has a direct relationship with its service quality (Correlation factor of 0.483 ) and since service quality is a function of rebranding, the research concludes that rebranding results in an increase $n$ the performance of the organization. Previous research has proven that employee satisfaction does have a positive influence on employee involvement (van van Wegge J. et al., 2007), performance of employees (Wright T., 2007), the employees' customer satisfaction (Stock 2009) and many other factors. Our research has further strengthened this assertion and went on further to provide an empirical link between corporate image, service quality and company performance.

\section{Conclusions}

A company may choose to rebrand as a corporate structural change in line with its current strategic direction some may rebrand in order to unite the organization behind one brand, align the culture, reestablish and reenergize the market position while at the same time embed a new vision, mission and values. Based on the results, we conclude that rebranding is crucial especially in the banking sector where technology is driving change and customer demands have become increasingly sophisticated. Rebranding can be one such solution as banks seek to align branding strategy to influence customer perceptions. We therefore accept the proposition that rebranding has a direct effect on consumer perceptions. 


\section{References}

Aaker, D. A., (1991). Managing Brand Equity: Capitalizing on the Value of a Brand Name. The Free Press, New York.

Aaker, A. D., (2010). Building strong brands. Pocket Books. London

Aaker, D. A., and Joachimsthaler, E. (2000b). Brand leadership. Simon \& Schuster. United Kingdom.

Anderson, E. W., Fornell, C and. Lehmann, D.R., (1994). Customer satisfaction, market share, and productivity: Finding from Sweden. Journal of Marketing, 58, 53-66.

Angur, G; Madhuka, N. and Jahera, S., (1999). Service quality in the Banking industry: an assessment in a developing economy. International Journal of Bank Marketing, 17(3), 116-123.

Alvarez, J. E., (2001). Your bank's image: keeping it consistent. Bank Marketing, 33(3), 30-35.

Balmer, J.M.T. and Gray, E.R., (2003). Corporate brands: what are they? What of them? European Journal of Marketing, 37, $972-997$.

Best, J.W., \& Khan, J.V., (1995). Research in Education. (7th Ed.). Prentice Hall: New Delhi.

Boyle, E., (2002). The Failure of Business Format Franchising in British Forecourt Retailing: A Case Study of the Rebranding of Shell Retail's Forecourts. International Journal of Retail and Distribution Management, 30(5), 251-63.

Brown, T.J., Dacin, P.A., Pratt, M.G., Whetten, D.A., (2006). Identity, intended image, construed image and reputation: an interdisciplinary framework and suggested terminology. Journal of the Academy of Marketing Sciences, 34(2), 99-106.

Causon, J., (2004). The Internal Brand: Successful Cultural Change and Employee Empowerment. Journal of Change Management, 4(4), 297-307.

Copper, R.D., and Schindler, S.P., (2003). Business Research Methods (8th Ed.). Tata: McGraw Hill//rwin

Cooper, H. M., (1988). The structure of knowledge synthesis. Knowledge in Society, 1, 104-126.

Clow, E. K. and Baack, D., (2007). Integrated advertising, promotion, and marketing communications. 3rd ed. Pearson Education Limited, Upper Saddle River. New Jersey.

Creswell, J.W. (2003). Research Design: Qualitative, Quantitative and Mixed Methods. Thousand Oaks, CA: Sage

Cronbach, L. J., (1951). Coefficient alpha and the internal structure of tests. Psychometrika, 16, 297-334.

Crowther, D. and Lancaster, G., (2009). Research Methods: A Concise Introduction to Research in Management and Business Consultancy. (2nd Edition). Oxford Butterworth-Heinemann.

Danesi, M., (2006). Brands. United Kingdom: Taylor \& Francis Inc.

Devlin, J.F., McKechnie, S., (2008). Consumer perceptions of brand architecture in financial services. European Journal of Marketing, 42(5/6), 654-666.

Doyle P., (1990). Building Successful Brands: The Strategic options. Journal of Strategic Marketing, 9, 255-268.

Evans, J.R and Berman, B., (2007). Marketing management: New Delhi,Aska press.

Grant, M. R. (2010). Contemporary Strategy Analysis. 7th ed. John Wiley \& Sons Ltd.

Allyson, H.; Krosnick, J. and Pfent, A., (2007). "The Causes and Consequences of Response Rates in Surveys by the News Media and Government Contractor Survey Research Firms." In Advances in telephone survey methodology. Sangster. New York: Wiley.

Ittner, C. D., and Larcker, D.F., (1998). Are nonfinancial measures leading indicators of financial performance? An analysis of customer satisfaction. Journal of Accounting Research, 36, 1-35.

Jankowicz, A. D., (1995). Business Research Projects (2nd Ed.). Chapman and Hall: London.

Kapferer, J.N., (2008). The new strategic brand management. 4th ed. Kogan Page Limited. London.

Kaikati, J. G., and Kaikati, A. M., (2003). A Rose by Any Other Name: Rebranding Campaigns That Work. The Journal of Business Strategy, 24(6), 1-18.

Keller, K.L., (1993). Conceptualizing, Measuring, and Managing Customer-based brand Equity. Journal of marketing, 57, 1-22.

Keller, K., (2003). Strategic Brand Management: Building. Measuring and Managing Brand Equity. 2nd ed. Englewood Cliffs, NJ: Prentice Hall.

Keller, K.L., (2006). Building, Measuring, and Managing Brand Equity. 2nd ed. Pearson Education International press.

Keller, K., (2008). Strategic brand management: building, measuring, and managing brand equity.3rd edition, Pearson international edition. Upper Saddle River, N.J.: Prentice Hall.

Kotler P et al., (1999). Principals of Marketing: Essex, Pearson Education limited.

Kotler P., (2001) .Marketing Management: Boston, Pearson custom publishing.

Kotler, P. Armstrong, G. and Tait, M., (2010). Global \& Southern African Perspectives: Principles of Marketing. South Africa: Pearson Education.

Kilic, C., and Dursun, T., (2006). The Effect of Corporate Identity Changes on Firm Value: An Empirical Investigation. Journal of the American Academy of Business, 10(1), 234-240.

Kim, H. B., Kim, W.G and An, J.A., (2003). The effect of consumer-based brand equity on firms' financial performance. Journal of consumer marketing 20 (4/5), 335-351.

Kim, H., and Kim, W., (2005). The relationship between brand equity and firm's performance in luxury hotels and chain restaurants', Tourism Management, 26, 549-560.

Kapp, D. E., (2000). The brand mindset. McGraw Hill. New York.

Lomax, W, Mador, M, \& Fitzhenry, A. (2002). Corporate rebranding: learning from experience. Occasional Paper Series, No 48.

Light, L. and Kiddon, J., (2009).Six Rules for Brand Revitalization. New Jersey: Pearson Education.

Madden, T. J., Fehle, F. and Fournier, S., (2005). Brands matter: an empirical demonstration of the creation of shareholder value 
through branding. Working paper, University of South Carolina.

Muzellec, L. and Lambkin, M., (2008).Corporate rebranding and the implications for brand architecture management: Journal of strategic marketing 16 (4), 283-299.

Solomon, M.; Bamossy, G.; Askegaard, S. and Hogg, M., (2006). Consumer Behavior. A European Perspective. 3rd revised edition. Prentice Hall, London.

Nandan, S., (2005). An exploration of the brand identity-brand image linkage: a communications perspective. Journal of Brand Management, 12 (4)264-278.

Nunnaly, J., (1978). Psychometric theory. New York: McGraw-Hill.

Percy, L and Rossiter, R. J., (1992). A Model of Brand Awareness and Brand Attitude Advertising Strategies. Psychology \& Marketing 4 (9), 263-274.

Polit, D.F., Beck, C.T., and Hungler, B.P., (2001). Essentials of Nursing Research: Methods, Appraisal and Utilization (5 $5^{\text {th }}$ Ed.). Lippincott Williams \& Wilkins: Philadelphia.

Romaniuk, J and Nicholls, E., (2005). Evaluating Advertising Effects on Brand Perceptions: Incorporating Prior Knowledge. International Journal of Marketing Research, 48(2), 179-192.

Rosenthal, G., (2003). A Name by Any Other Name: Responding to Increasing Role of Marketing in Higher Education. Doctoral Dissertation, University of Pennsylvania.

Saunders, M., Lewis, P, and Thornhill, A., (2005). Research Methodology for Business Studies. $3^{\text {rd }}$ Ed. Pearson Education: Singapore.

Skogland, I., and Siguaw, J.A., (2004). Are your satisfied customers loyal? Cornell Hotel and Restaurant Administration Quarterly, 45 (3), $221-234$.

Stern, B.B., (2006). What does brand mean? Historical-analysis method and construct definition. The Journal of the Academy of Marketing Science, 34(2), 216-23.

Stuart, H., and Muzellec, L. (2004). Corporate make-overs: can a hyena be rebranded. Journal of Brand Management, 11, 472-482.

Wheeler, A., (2006). Design Brand identity: A complete guide to creating, building and maintaining strong brands.2nded.John Wiley \& Sons, Hoboken, New Jersey.

Van Wegge, J.; Parkes, C; Dick, R., (2007).Taking a Sickie: Job Satisfaction And Job Involvement As Interactive Predictors of Absenteeism In A Public Organization. Journal of Occupational and Organizational Psychology, 80(1), 77-89.

Wright, T., Cropanzano, R. and Bonett, D.G., (2007). The Moderating Role of Employee Positive Well Being on the Relation between Job Satisfaction and Job Performance. Journal of Occupational Health Psychology, 12 (2), 93-104. 